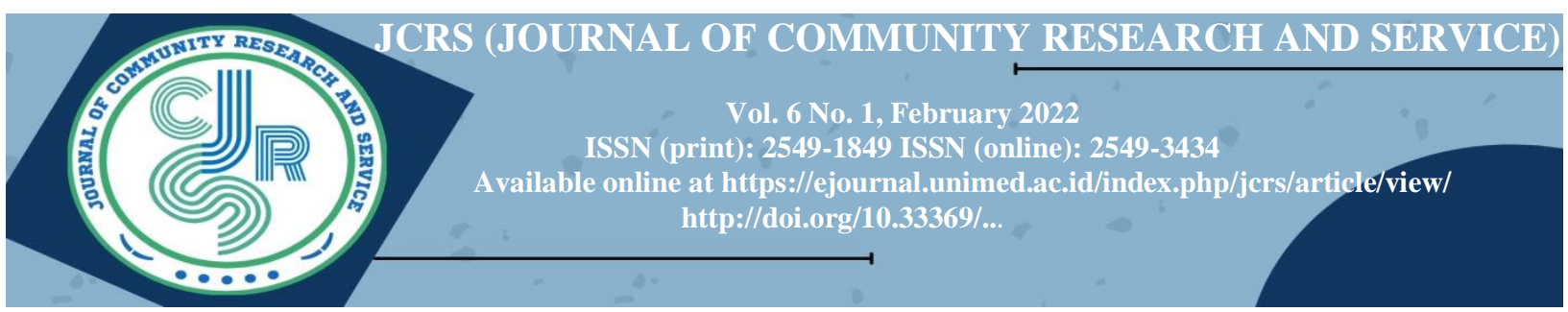

\title{
Providing Supplementary Food to Nutritional Children and Application of Food Processing Process Technology and Economic Empowerment
}

\author{
${ }^{1}$ Rasita Purba, ${ }^{2}$ Hidir Efendi \\ ${ }^{1}$ Department of Culinary Education, Faculty of Engineering, Universitas Negeri Medan, \\ INDONESIA \\ ${ }^{2}$ Department of Mechanical Engineering Education, Faculty of Engineering, Universitas \\ Negeri Medan, INDONESIA \\ ${ }^{1}$ rasita.purba@yahoo.com
}

\begin{abstract}
Fish has good potential to overcome malnutrition problems such as lack of energy and protein (PEM), lack of vitamin A, disorders due to lack of iodine, and nutritional anemia, while tempeh-based formulas can shorten the duration of acute diarrhea and accelerate weight gain after suffering from one illness. episodes of acute diarrhea. Tempe and fish are easier to digest because of their high content of free fatty acids, peptides, and amino acids. The objectives of this IbM activity are (1) the design of more spin machines, (2) the production of forte cookies and fish meal cookies, (3) the production of various processed fish, packaging, and nutritional status. Specific targets to be achieved; There are variations of PMT Toddlers to improve the nutritional status of toddlers, production of processed fish through the application of food processing technology, packaging, and economic empowerment of fishing communities. The approach method used is the method of education, production training, business management training, design, and assistance. The results of this IbM program activity are more spin machines with a drying capacity of $10 \mathrm{~kg} / 30$ minutes, additional food products (PMT) for toddlers in the form of forte cookies, fish flour cookies, and various processed fish products. Conclusion: Organoleptic tests for taste, aroma, texture, and color, showed positive responses from IbM partners and participants, as well as responses from local people who tasted the product. The nutritional knowledge of the cadres is good (87.3\%), making forte and fish meal (91\%), making various kinds of processed fish (91.6\%). The nutritional status of children under five is still under the category of malnutrition (36\%). Selling processed fish products is still (28\%). The production of a variety of processed fish.
\end{abstract}

Keywords: Spiner machine, Cookies Forte, Cookies Fish meal, Processed fish products, Packaging, Nutritional Status

Article history: Received: 02-12-2021; Revised: 10-12-2021; Accepted: 04-02-2022; Available online: 26-02-2022 How to cite this article: Purba, R., Efendi, H. (2022) Providing Supplementary Food to Nutritional Children and Application of Food Processing Process Technology and Economic Empowerment. Journal of Community Research and Service, 6(1), $\mathrm{xxx}-\mathrm{xxx}$.

https://doi.org/10.14710/ijred.x.X.xxx-xxx

\section{Introduction}

Nutritional problems are public health problems that cannot be overcome by medical approaches and health services alone. Nutritional problems besides being a poverty syndrome are closely related to food security problems at the household level, they also involve aspects of knowledge and behavior that do not support a healthy lifestyle.

Fish as food has high nutritional value with minerals, vitamins, fats, and proteins arranged in essential amino acids which are indispensable for human growth and intelligence. Fish oil supplementation was effective in providing omega-3 fatty acids which are important for brain development in children under five [1]. Thus, fish have good enough potential to overcome malnutrition problems such as lack of energy and protein (KEP), lack of vitamin A, disorders due to lack of iodine, and nutritional anemia [2].

Tempe, a food ingredient derived from soybeans, has a high nutritional value. Tempe is rich in fiber, 
calcium, B vitamins and iron has better content and digestibility than soybeans. Therefore, tempeh is very good to be given to toddlers. Tempe is easy to digest because of its high content of free fatty acids, peptides, and amino acids. [3].

Based on the study, children who received a mixture of tempe-wheat food ingredients stopped diarrhea after $2.39 \pm 0.09$ days (mean), faster than children who received a mixed diet of rice-milk (mean $2.94 \pm$ 0,33 days) [4]. A double-blind randomized controlled clinical trial study showed that a tempe-based formula could shorten the duration of acute diarrhea and accelerate weight gain after suffering one episode of acute diarrhea [5].

The objectives of the IbM activities are addressing the low use of fish in PMT for children under five, providing materials for fish and tempeh, making a forte, fish meal, and products, training on the production of cookies and various processed fish products, management and packaging training.

Empowerment of fishermen's mothers is still difficult to develop, this is due to the condition of education which is generally very low, lack of science and technology, and poverty that always supports fishing areas, so cases of malnutrition are frequent in toddlers. To anticipate the situation mentioned above, it is necessary to pursue an empowerment program for posyandu cadres and fishing communities, this program is essentially directed through a food processing technology approach, providing additional food (PMT) and empowering the community's economy by developing various potential human resources and natural resources in the area. fishing areas, management, and entrepreneurship as well as appropriate technology that leads to improving product quality, of course, this will further increase the role of posyandu cadres and the fishing community to improve the nutritional status of toddlers and the family economy.

The quality of production has been strived to be as good as possible, but due to the limited knowledge of nutrients from tempeh and fish, the application of food processing technology, and appropriate technology, through this IbM Program activity it is possible to develop product technology for processed Cookies Forte, Fish Flour Cookies as PMT. to improve the nutritional status of children under five and various processed fish productions (fish shredded, fish nuggets and tempeh, meatballs and fish sausage) and packaging to empower the economy of fishing communities. In line with the development of food science and technology and nutrition, in the last decade, more and more varied food ingredients have been found that have high nutritional quality, but because they have not become one of the main foods in fishing communities, especially fish which are rich in nutrients, these foodstuffs are not utilized optimally.

\section{Method}

The approach method used is the method of education, production training, business management training, design, and assistance. From the problems that have been stated above and to achieve the expected goals, the working procedures to support the realization of the proposed approach are as follows:

1) Provide educational methods and knowledge about the nutritional content of tempeh and fish, which are very beneficial for health, especially for improving the nutritional status of children under five and empowering the community's economy.

2) Making a more spin machine (oil drain) with the design method and the method of assisting the application of the machine to partners. This machine is effective with $10 \mathrm{~kg} / 30 \mathrm{~min}$ oil drain capacity, easy operation.

3) Provide food processing technology with production training methods for making forte cookies and fish meal cookies and mentoring methods, so that cookies are produced that are rich in nutrients.

4) Provide processing technology for various processed fish productions such as shredded, nuggets, meatballs, and fish sausages, food safety using education and production training, because food produced to be sold to the general public, should be guaranteed of good quality and safe for consumption.

5) Provide packaging technology, because packaging also plays an important role in the progress of a business. Slick packaging will also determine the success of marketing a product.

6) Provide business management training, to improve the skills of business owners (partners) in implementing management in the fields of organization, production, finance, administration, product selling prices, consumers, and marketing techniques. 


\subsection{Activity Implementation}

The implementation team conducted a field survey to the Pekan Labuhan Village area to see the condition of children under five and the fishing community. The team saw children who were not healthy, the environment was not clean, the potential of fish was sufficient, so the team made these posyandu cadres and fishing communities the target audience (partners) in the IbM program activities.

The materials used were: 1) Fish and tempe; 2) Flour, eggs, butter, sugar, butter; 3) Seasoning, chocolate, t. milk, etc., and the tools used were: Gas stoves/tubes, Mixer, Blender, Scales, Oven, Presto, Basin, Frying Pan, Pans, and Cake molds. Tool Design, Performance, and Productivity Spiner machines are designed with the design principles of tool elements including stainless tabs, regulators, frames, temperature gauges. The productivity of the machine is effective and efficient with a draining capacity of $10 \mathrm{~kg} / 30$ minutes.

The implementation of science and technology activities for the community (IbM) starts from the preparation stage, implementation in the field, and reporting for eight months. Step by step evaluation is carried out by the education material plan, design, production training, and mentoring that will be delivered and implemented. Education and training activities were carried out in business partners in the Village of Pekan Labuhan and Kelurahan Nelayan Indah, Medan Labuhan District, Medan City, carried out for 5 months. The number of training participants is 25 people. The opening ceremony of the training was attended by business partners of Posyandu Cadres, fishing communities, and Mr. Fauzi Chan from Pekan Labuhan Village. The opening of the training was carried out by Mr. Fauzi Chan on behalf of the Village Head of Pekan Labuhan, which was previously preceded by several remarks, namely the remarks of the Chief Executive of the Activity (Dra. Rasita Purba, M.Kes, accompanied by Member Drs. Hidir Efendi, M.Pd and the students involved ) and the Chairperson of the Medan State University LPM (Dr. Ridwan A, Sani M.Si), represented by his staff, Mr. Azroi, and community leaders.

Broadly speaking, the training activities are divided into four, namely, pre-test, providing material (knowledge) about fish and tempeh as food, nutrient content and utilization of fish and tempeh in the manufacture of PMT products, provision of materials (soft skills), the practice of making forte, fish meal and processed fish products, use of spinner machines and impulse sealers that directly involve participants (hard skills), evaluation of training results and post-tests. With sufficient understanding and practice, it is expected to increase the use of forte, fish meal, and processed fish products that have not been utilized by partners for PMT for children under five, so far, children under five are only given mung bean porridge, bread, fried tofu, eggs, and cakes occasionally. While the use of fish and tempeh has the prospect of being used as food products favored by children under five, they are the best alternative that can be offered to posyandu cadres.

Material debriefing was given on the first day after the opening ceremony by the presenters who were the implementing team. The purpose of this material is to provide participants with knowledge and understanding of seven things:

1) Knowledge of fish forte (Tempe formula), the nutritional content of tempeh and fish as well as potential prospects for processed products such as forte cookies, fish meal cookies, and processed fish products, as PMT for children under five, can be marketed, increasing the income of fishing communities (Dra, Rasita Purba, M.Kes and students).

2) The process of making forte flour, fish meal, cookie products, and processed fish products (submitted by Dra. Rasita Purba, M.Kes and the students involved).

3) The technique of designing a spinner machine with a drying capacity of $10 \mathrm{~kg} / 30$ minutes (done by Drs. Hidir Efendi, M.Pd in the FT workshop).

4) Product packaging (done by Dra. Rasita Purba, M.Kes).

5) Giving products to toddlers

6) Business management training, to improve the skills of Posyandu cadre partners and fishing communities in implementing management in the business sector (submitted by Drs, Hidir Efendi, M.Pd).

7) Evaluation of training activities (by the IbM Team). 


\subsection{Activities}

1) Opening of IBM Activities and Providing Materials
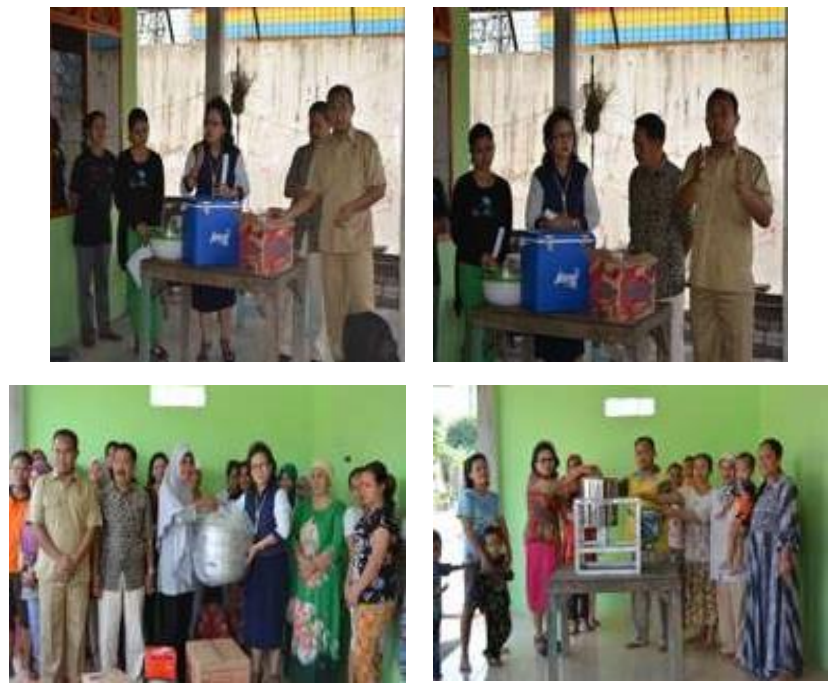

Fig. 1. Opening and Activities.

2) Material Giving Activities

Provision of Materials The formation of hard skills is focused on forte, fish meal, and product making activities which are carried out by direct practice by partners / presenters.

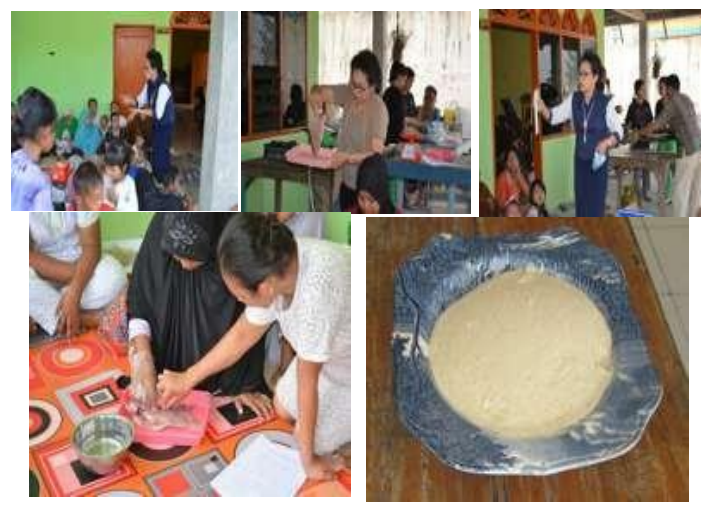

Fig. 2. Flour making training.

3) Spinner Machine Manufacturing Process Activities
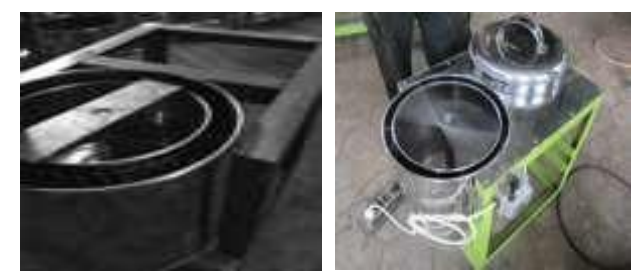

Fig. 3. Machine Manufacturing Process. 
4) Fish Products and Cookies Processing Activities
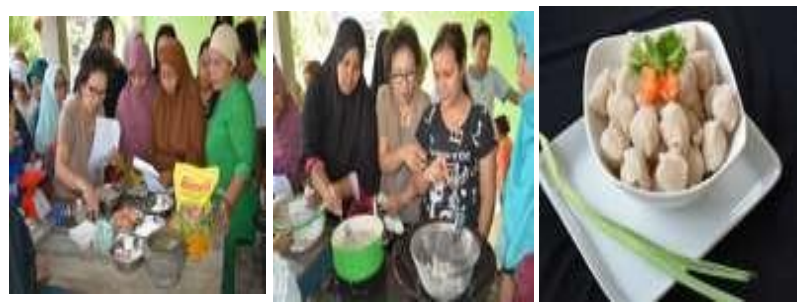

Fig. 4. Training on Making Fish Meatballs.

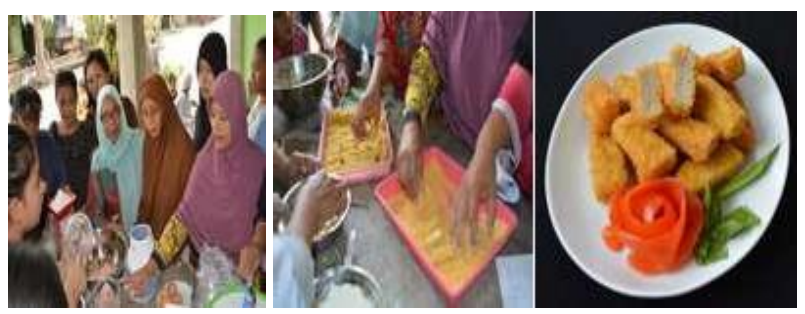

Fig. 5. Training on Making Fish Nuggets.
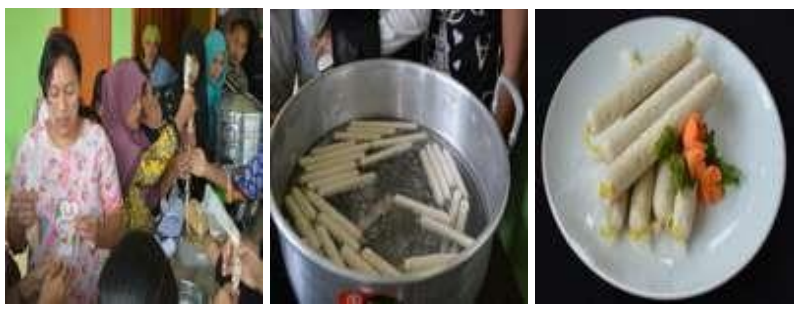

Fig. 6. Training on Making Fish Sausage.

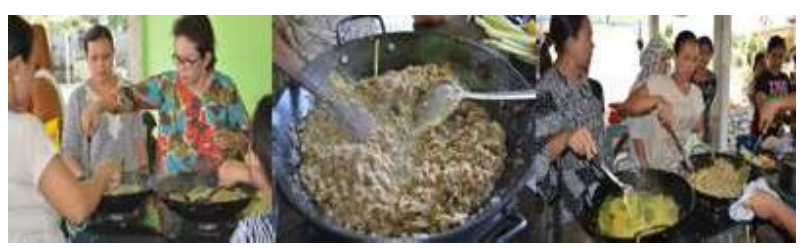

Fig. 7. Training on Making Shredded Fish.

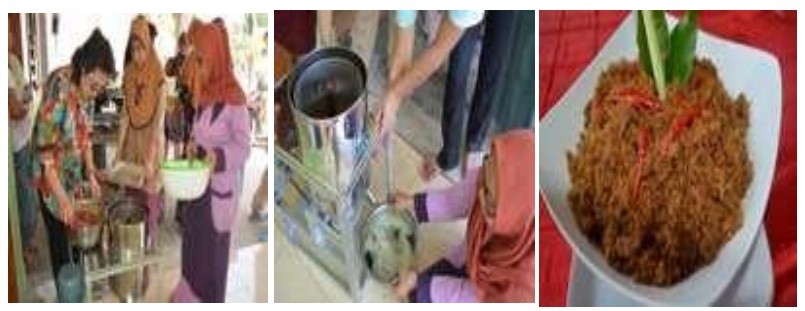

Fig. 8. Oil Drain Training. 


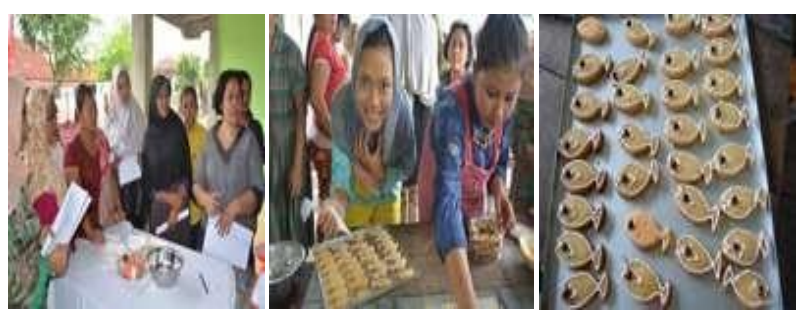

Fig. 9. Cookies Making Training.

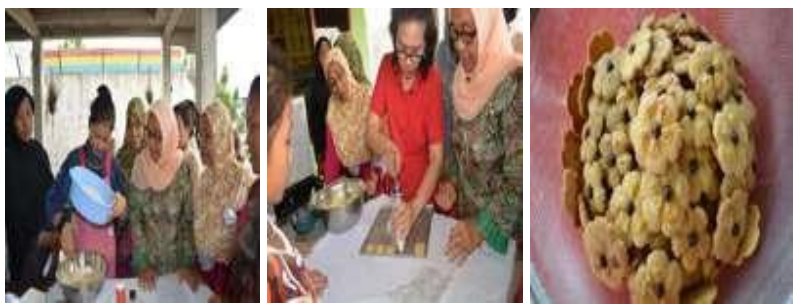

Fig. 10. Cookies Making Training.

5) Product Packaging Activities
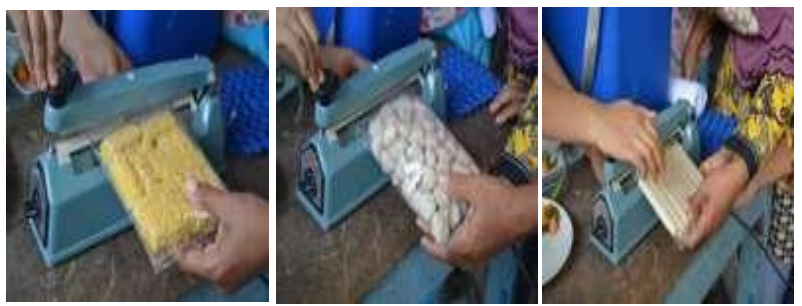

Fig. 11. Product Packaging Training.

6) Giving Products to Toddlers
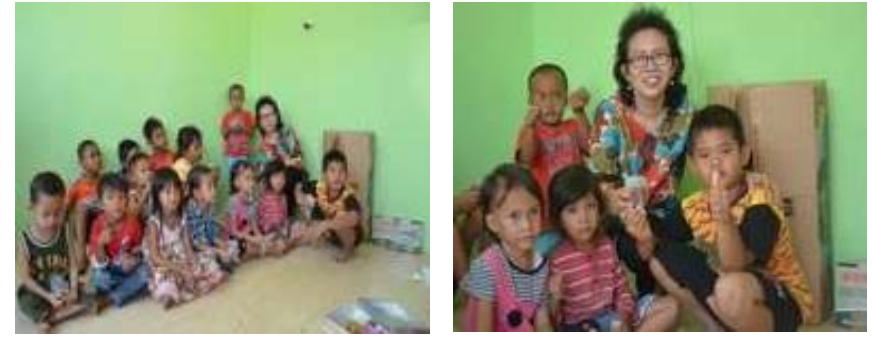

Fig. 12. Provision of Toddler Products.

7) Evaluation of Training Activities

To determine the success of the implementation of science and technology for the community, the following performance indicators are needed: a) Increased knowledge and skills of partners. b) Increased knowledge and skills of partners in the manufacture of forte flour and fish meal. c) Increased knowledge and skills of cookie processing. d) Increased knowledge and skills of processing various processed fish.

\section{Findings and Discussion}

The results of this IbM program activity are one more spin machine, forte flour and fish meal, cookie products, various processed fish, and packaging. The implementation of this activity went smoothly as planned. This activity is carried out in an effort to deal with the low consumption of fish and tempeh in PMT products for children under five (animal and vegetable protein), which has been experienced by posyand $u$ cadres and fishing communities to utilize these foodstuffs, this is due to the limited knowledge of partners about the nutritional content of fish. and tempeh, flour manufacturing technology, cookies 
processing technology and processing technology for various processed fish. Product results can be seen in Figure 13.

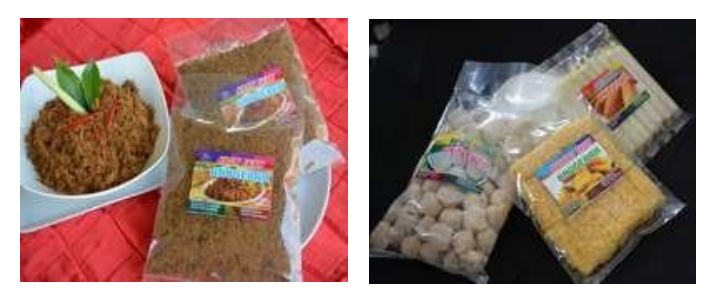

Fig. 13. Processed Fish Products.

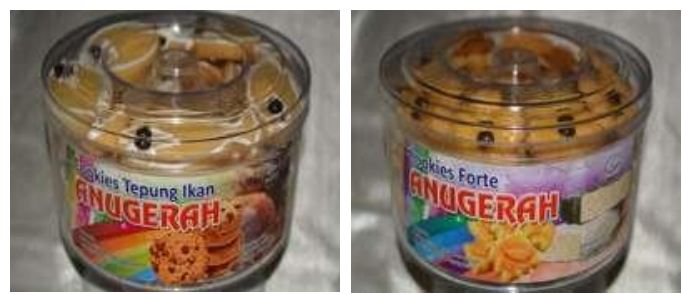

Fig. 14. Cookies Products.

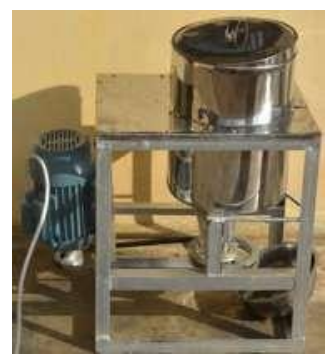

Fig. 15. Spiner Machine.

This spinner machine is effective and efficient, capable of draining oil in the amount of $10 \mathrm{~kg} / 30$ minutes, resulting in a crispy shredded fish that is not rancid due to oil. The results of organoleptic tests for forte cookies, fish meal cookies, and processed fish products, for taste, texture, aroma, and color, showed a positive response from IbM partners and participants and the product was feasible to be marketed.

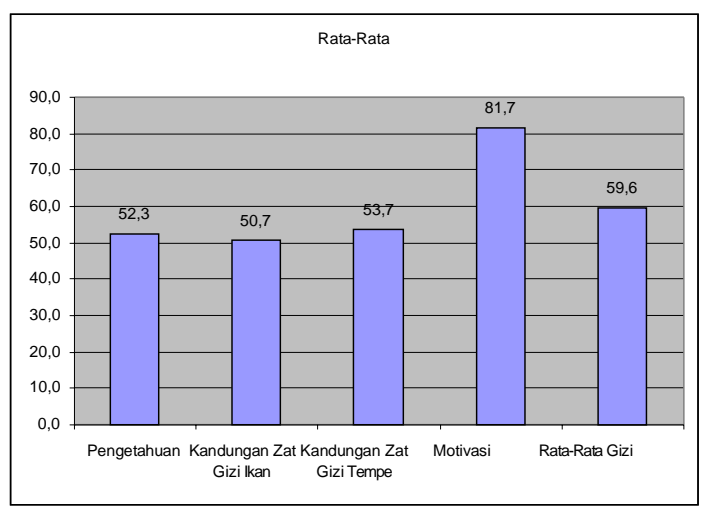

Fig. 16. Knowledge Pre-test Graph. 


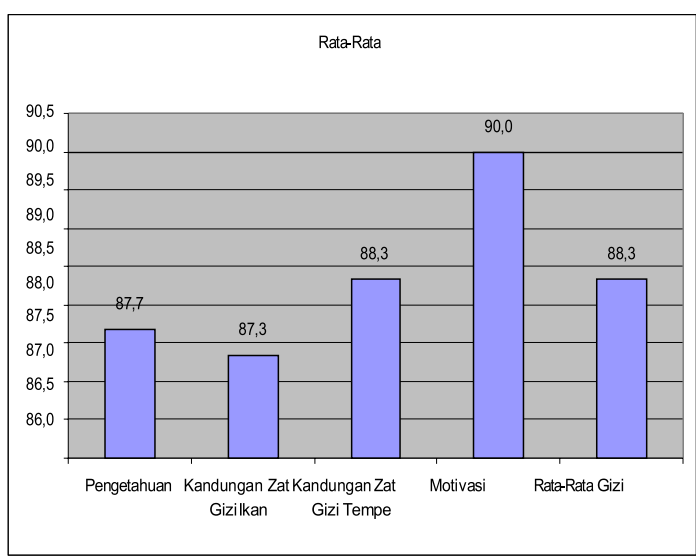

Fig. 17. Knowledge Post-test Graph.

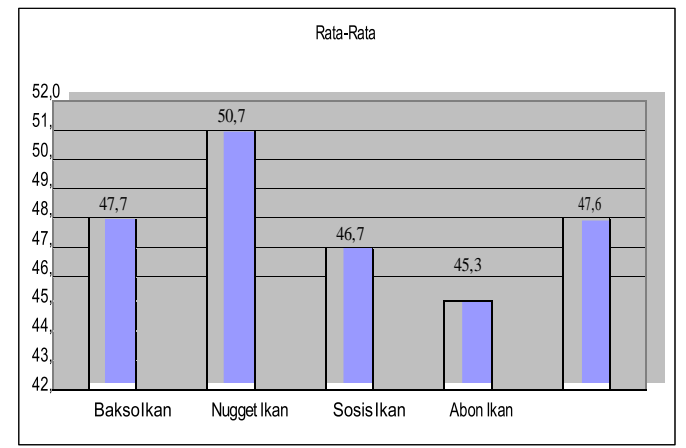

Fig. 18. Graph of Pre-Test Processing.

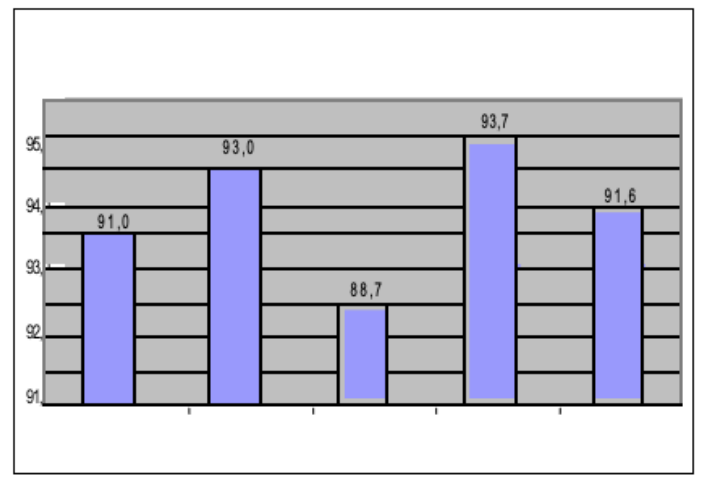

Fig. 19. Post-Test Processing Graph.

\subsection{Efficiency and Economical Analysis of Activities}

Table 1. Results of the Nutritional Status Test for Toddlers.

\begin{tabular}{|c|c|c|c|c|c|}
\hline \multirow[t]{2}{*}{ No } & \multirow{2}{*}{$\begin{array}{c}\text { Nutritional } \\
\text { status }\end{array}$} & \multicolumn{2}{|c|}{ Before } & \multicolumn{2}{|c|}{ After } \\
\hline & & Quantity & $\%$ & Quantity & $\%$ \\
\hline 1. & Good & 5 & 20 & 6 & 24 \\
\hline 2. & Fair & 7 & 28 & 10 & 40 \\
\hline 3. & Less & 13 & 52 & 9 & 36 \\
\hline & & 25 & $100 \%$ & 25 & $100 \%$ \\
\hline
\end{tabular}




\section{Conclusion}

The conclusions that can be drawn from the results of the implementation of this service are: 1) Knowledge of nutrition and motivation of posyandu cadres and fishing communities towards IbM activities and the development of processed fish products are good. 2) The productivity of the designed spinner machine is $10 \mathrm{~kg} / 30$ minutes. 3) Posyandu cadres and fishing communities $91 \%$ have been able to make forte flour and fish meal. 4) Posyandu cadres and fishing communities $91.6 \%$ have been able to make a variety of processed fish products. 5) The results of organoleptic tests for taste, aroma, texture, and color showed a positive response from IbM partners and participants, as well as responses from the surrounding community who tasted the product. Cost analysis of the production produced with this technology is profitable

The recommendations for further study are: 1) Posyandu cadres and fishing communities to take advantage of the catch of small fish to be processed into a product that has a selling value and can be used as PMT for children under five. 2) Efforts need to be made to introduce a variety of processed forte and fish products to the community around the Pekan Labuhan and Nelayan Indah Villages, through the cooperation of the Fisheries Service to introduce the product, so that it becomes a characteristic food of the Pekan Labuhan Village.

\section{References}

[1] Arbuckle LD, Rioux F, Mackinnon MJ, Hrboticky N, Innis S. Response of (n-3) and (n-6) Fatty Acids in Piglet Brain, Liver and Plasma to Increasing, but Low, Fish Oil Supplementation of Formula. The Journal of nutrition. 1991; 121(10):1536 - 1547.

[2] Karyadi S, Sudirman H. Potensi Gizi Hasil Laut Untuk Menghadapi Masalah Gizi Ganda, Risalah Widyakarya Pangan dan Gizi V. LIPI Jakarta; 1994: 157 - 175.

[3] Sutomo, B. Cegah Anemia dengan Tempe. 2008. http://myhobbyblogs.com/food/files/ 2008/06/ Diakses tanggal 18 Oktober 2021.

[4] Mardiah. Sifat Fungsional \& Nilai Gizi Tepung Tempe Serta Pengembangan Produk Olahannya Sebagai Makanan Tambahan Bagi Anak. Bogor; Institut Pertanian Bogor: 1994.

[5] Soenarto et al. Antidiarrheal characteristics of tempe produced traditionally and industrially in children age 6-24 months with acute diarrhea dalam Soenarti, S.Y. Diarrhea case management: Using research finding page directly for case management and teaching in a teaching hospital in Yogyakarta, Indonesia. 1997: 99. 